\title{
RADIOACTIVE RESIDUE IN HONEY
}

\author{
Željko Mihaljev', Sandra Jakšić ${ }^{1}$, Milica Živkov Baloš ${ }^{{ }^{*}}$, Nenad Popov ${ }^{1}$ \\ ${ }^{1}$ Scientific Veterinary Institute "Novi Sad“, Novi Sad, Republic of Serbia
}

\section{Abstract}

The concentration of radioactive isotopes in honey is an important bioindicator of environmental contamination. For that purpose, a total of 66 samples of different types of honey (acacia, meadow, linden, sunflower, flower, oilseed rape, chestnut) were examined. The samples were collected during 2020 and 2021 at different localities in the Republic of Serbia (Vojvodina, Central Serbia, Kosovo and Metohija). Gamma spectrometric analysis was used to determine natural radionuclides potassium- $40\left({ }^{40} \mathrm{~K}\right)$, thorium-232 $\left.{ }^{232} \mathrm{Th}\right)$, radium-226 $\left.{ }^{226} \mathrm{Ra}\right)$, uranium-238 $\left({ }^{238} \mathrm{U}\right)$, uranium-235 $\left({ }^{235} \mathrm{U}\right)$ and sodium-22 $\left({ }^{22} \mathrm{Na}\right)$ and anthropogenic radionuclide caesium-137 $\left({ }^{137} \mathrm{Cs}\right)$. The obtained results indicate that the predominant radionuclide in all the analyzed honey samples is natural $\mathrm{K}-40$, whose average activity was $74 \mathrm{~Bq} / \mathrm{kg}$. The activity of other tested radionuclides ranged as follows: Th232: < 1 - 2.0; Ra-226: 1.9 - 15.6; U-238: $<1$ - 31.4; U-235: $<0.2$ - 1.61 and $\mathrm{Na}-22:<0.2-2.4 \mathrm{~Bq} / \mathrm{kg}$. The activity of the artificial radionuclide Cs-137 was measured in $53 \%$ of the tested samples from the territory of Kosovo with the maximum value of $3.63 \mathrm{~Bq} / \mathrm{kg}$. Regarding the determined level of radioactive residues, it can be concluded that the honey produced in the Republic of Serbia is healthy and environmentally safe food.

Key words: honey, natural radionuclides, artificial radionuclides

1*Corresponding Author: milica@niv.ns.ac.rs 


\title{
RADIOAKTIVNE REZIDUE U MEDU
}

\author{
Željko Mihaljev ${ }^{1}$, Sandra Jakšić ${ }^{1}$, Milica Živkov Baloš ${ }^{1 *}$, Nenad Popov ${ }^{1}$ \\ ${ }^{1}$ Naučni institut za veterinarstvo „Novi Sad“, Novi Sad, Republika Srbija
}

\section{Kratak sadržaj}

Koncentracija radioaktivnih izotopa u medu predstavlja važan bioindikator kontaminacije životne sredine. $U$ tom cilju ispitano je ukupno 66 uzoraka različitih vrsta medova (bagremov, livadski, lipov, suncokretov, cvetni, kestenov i od uljane repice, ). Uzorci su sakupljeni u toku 2020/2021 godine sa različitih lokaliteta Republike Srbije (Vojvodina, centralna Srbija, Kosovo i Metohija). Gama-spektrometrijskom analizom određivani su prirodni radionuklidi kalijum-40 $\left({ }^{40} \mathrm{~K}\right)$, torijum-232 $\left({ }^{232} \mathrm{Th}\right)$, radijum-226 $\left({ }^{226} \mathrm{Ra}\right)$, uran-238 $\left({ }^{238} \mathrm{U}\right)$, uran-235 $\left({ }^{235} \mathrm{U}\right)$ i natrijum-22 $\left({ }^{22} \mathrm{Na}\right)$ kao i antropogeni radionuklid cezijum-137 $\left({ }^{137} \mathrm{Cs}\right)$. Dobijeni rezultati ukazuju da je predominantni radionuklid u svim analiziranim uzorcima meda prirodni K-40, čija je prosečna aktivnost iznosila $74 \mathrm{~Bq} / \mathrm{kg}$. Aktivnost ostalih ispitanih radionuklida kretala se u intervalu za Th-232: < 1 - 2.0; za Ra-226: 1.9 - 15.6; za U-238: < 1 - 31.4; za U-235: < 0.2 - 1.61 i za Na-22: < 0.2 - 2.4 Bq/ $\mathrm{kg}$. Aktivnost veštačkog radionuklida Cs-137 izmerena je u 53\% ispitanih uzoraka sa područja Kosova sa maksimalnom vrednošću od $3.63 \mathrm{~Bq} / \mathrm{kg}$. $S$ obzirom na utvrđeni nivo radioaktivnih rezidua može se zaključiti da je med proizveden u Republici Srbiji zdrava i ekološki bezbedna hrana.

Ključne reči: med, prirodni radionuklidi, veštački radionuklidi

\section{INTRODUCTION}

Rapid development of industry and technology worldwide is leading to an increase in global environmental pollution. This can result in the presence of a large number of contaminants of various origins in foods for human consumption, with radionuclides being the most significant ones. They are primarily the result of the application of nuclear energy for peacetime use. Past accidents at nuclear power plants (Chernobyl, 1986; Fukushima, 2011) have caused high levels of radioactive contamination of the biosphere. Increased content of radionuclides in agricultural land as a result of the use of artificial phosphate fertilizers and coal combustion in thermal power plants with their solid waste (ash, slag) are the most important source of "technologically increased natural 
radioactivity" because they contain natural radionuclides (uranium, thorium) and their derivatives. Also, during the bombing in 1999, the territory of the Republic of Serbia was contaminated with depleted uranium and the consequences of this are long-term and unforeseeable. All these factors indicate that it is significant to measure the level of radioactivity in the environment and predict the effects it might have for the flora and fauna, humans and ecosystems in different ways in the years to come (Blagojević and Simić, 2012). These sources of radioactive contamination provide ample opportunities for disturbing the ecological balance because they are by far the largest anthropogenic source of increasing the content of radionuclides in the soil, and therefore also in plants and other links in the food chain. Honey bee (Apis mellifera) has an extremely important and complex role in nature because it affects the production of human and animal food, various industrial raw materials of agricultural origin as well as human health. However, the conditions for beekeeping have been deteriorating for a long time because plants absorb various harmful substances like radionuclides, through roots, leaves and flowers - and the flowers of plants are the main sources of bee food, nectar and pollen. It has also been documented (Mihaljev et al., 1992) that honey contains chemical components of plants. Honey bees collect pollen and nectar from the environment, so the content of elements and their amount in honey depends on environmental conditions. Honey is a food that is exclusively a product of honey bees. Its quality depends on the type and geographical origin, environmental conditions, the origin of bees, the method of processing and storage. It is not allowed to change the composition of honey by adding some substances.

Bees are a part of nature and represent one of the most nutritious foods, which is rich in many nutrients of great physiological and preventive value for the human body. However, bees are also exposed to radioactive substances, i.e., ionizing radiation that is in the environment. Some observations after the Chernobyl nuclear disaster showed that in some areas bees had very intense reaction to increased radioactivity like anxiety, disorientation and mass abandonment of hives (Vorgić, 2004). Increased content of radionuclides on bee pastures can affect general health of bees, and the presence of radionuclides in honey can significantly change the quality of this high-quality food. Given the characteristics of honey (Stanimirović et al., 2000), which imply a relatively wide area where bees collect nectar, honey is certainly one of the potential bioindicators of radioactive contamination. 


\section{MATERIAL AND METHODS}

A total of 66 honey samples (acacia, meadow, linden, sunflower, flower, oilseed rape, chestnut) were collected from 2020 to 2021. The specific activities of caesium-137 $\left({ }^{137} \mathrm{Cs}\right)$, potassium-40 $\left({ }^{40} \mathrm{~K}\right)$, uranium-238 $\left({ }^{238} \mathrm{U}\right)$, uranium-235 $\left({ }^{235} \mathrm{U}\right)$, radium-226 $\left({ }^{226} \mathrm{Ra}\right)$, thorium-232 $\left({ }^{232} \mathrm{Th}\right)$ and sodium-22 $\left({ }^{22} \mathrm{Na}\right)$ were determined using a coaxial HPGe detector (ORTEC-AMETEK, GEM25P4-70) with an energy resolution of $1.67 \mathrm{keV}$ at the $1.33 \mathrm{MeV}$ of ${ }^{60} \mathrm{Co}$, Peak-to-Compton ratio 67:1 (Amp Shape Time 6us) and the relative efficiency of $28 \%$. The detector was housed in a $10 \mathrm{~cm}$ thick lead shield lined by copper layer, cadmium layer and a layer of plexiglass (IAEA, 1989). The instrument was calibrated by the accredited laboratory for gamma-ray spectroscopy calibration and activity of radioactive sources of gamma emitters - Chair of Nuclear Physics, Department of Nuclear Physics, Faculty of Sciences, University of Novi Sad. The precision and accuracy of the instrument operation was controlled using standard reference material Source No. LR 320 certified by the Calibration Laboratory for Measurements of Radioactivity (Deutscsher kalibrierdienst, Braunschweig, Germany).

The counting time for each sample was $100,000 \mathrm{~s}$, and the analytical precision of the measurement was approximately $\pm 10 \%$. The specific activity of ${ }^{238} \mathrm{U}$ was calculated from gamma-rays of ${ }^{234} \mathrm{Th}$ at $63.3 \mathrm{keV}$ and gamma-rays $\mathrm{Pa}$ $234 \mathrm{~m}(1001 \mathrm{keV})$. The specific activity of ${ }^{226} \mathrm{Ra}$ was determined from the peak areas at $609.3,1120.3$ and $1764.5 \mathrm{keV}$ of ${ }^{214} \mathrm{Bi}$ and 295.2 and $351.9 \mathrm{keV}$ of ${ }^{214} \mathrm{~Pb}$. Gamma-ray peaks with energies 911.2 and $969.0 \mathrm{keV}\left({ }^{228} \mathrm{Ac}\right)$ and gamma-ray doublet $238.6 \mathrm{keV}\left({ }^{212} \mathrm{~Pb}\right)$ and $241 \mathrm{KeV}\left({ }^{214} \mathrm{~Pb}\right)$ as well as Tl-208 $(583.2 \mathrm{KeV})$ were used for calculation of the specific activities of ${ }^{232} \mathrm{Th}$. Specific activities of ${ }^{40} \mathrm{~K}$ and ${ }^{137} \mathrm{Cs}$ were determined using their own $1460.8 \mathrm{keV}$ and $661.7 \mathrm{keV}$ peaks, respectively (Bikit et al., 1995).

Input signals to the detector through ORTEC type pre-amplifiers and spectra amplifiers were channelled to a multichannel analyser MCA with an analog-to-digital converter of 16384 channels total memory. MCA was directly connected with PC where the measured spectra were stored and analysed. The gamma spectra were acquired and analysed using the GammaVision software. This program calculates the activity concentration of an isotope from all prominent gamma lines after background subtraction. All the measurement of uncertainties are presented at $95 \%$ confidence level. The measured specific activity of ${ }^{137} \mathrm{Cs}$ was decay corrected to the sampling date (Ortec, 2015). 


\section{Results}

The content of radioactive substances - radionuclides on honey plants is the result of the transfer of radioactive fallout from the atmosphere through air currents, water (rain, snow, erosive processes) and soil, or their direct and indirect reach to crops of meadows, pastures and forests. Gamma-spectrometric analysis in the examined samples of honey determined the presence of natural radionuclides, namely: sodium-22, potassium-40, thorium-232, radium-226, uranium-238 and uranium-235. The results of the measured activities of these radionuclides are shown in Table 1 and Table 2.

Table 1. The results of measurements of radionuclides in honey from the area of Vojvodina and Central Serbia

\begin{tabular}{llllllll}
\hline Radionuclides & $\begin{array}{l}\text { Cs- } \\
\mathbf{1 3 7}\end{array}$ & K-40 & Th-232 & Ra-226 & U-238 & U-235 & Na-22 \\
\hline $\begin{array}{l}\text { Type of honey } \\
\text { (number of } \\
\text { samples) }\end{array}$ & Activity concentration & {$[\mathbf{B q} / \mathbf{k g}]$} & & & \\
\hline $\begin{array}{l}\text { 1. Meadow } \\
\text { honey (n=11) }\end{array}$ & $<0.5$ & $54 \pm 4$ & $<2$ & $1.9 \pm 1.0$ & $<10$ & $<1$ & $2.2 \pm 1.0$ \\
\hline $\begin{array}{l}\text { 2. Acacia } \\
\text { (n=9) }\end{array}$ & $<0.5$ & $55 \pm 6$ & $<1$ & $<1$ & $<10$ & $<1$ & $<1$ \\
\hline $\begin{array}{l}\text { 3. Flower } \\
\text { (n=8) }\end{array}$ & $<0.5$ & $34 \pm 2$ & $1.8 \pm 0.6$ & $4.7 \pm 1.1$ & $14.3 \pm 3$ & $0.73 \pm 0.15$ & $1.8 \pm 1$ \\
\hline $\begin{array}{l}\text { 4. Sunflower } \\
(\mathbf{n}=10)\end{array}$ & $<0.5$ & $32 \pm 2$ & $<1$ & $3.2 \pm 1.0$ & $16.6 \pm 4.0$ & $0.85 \pm 0.05$ & $2.2 \pm 0.5$ \\
\hline $\begin{array}{l}\mathbf{5 . ~ L i n d e n ~} \\
\text { (n=4) }\end{array}$ & $<0.5$ & $41 \pm 3$ & $2.0 \pm 0.7$ & $6.6 \pm 1.4$ & $<10$ & $<1$ & $<1$ \\
\hline $\begin{array}{l}\text { 6. Oilseed } \\
\text { rape (n=6) }\end{array}$ & $<0.5$ & $74 \pm 2$ & $<0.5$ & $11.1 \pm 1.8$ & $21.5 \pm 5.1$ & $1.0 \pm 0.01$ & $2.2 \pm 1.0$ \\
\hline $\begin{array}{l}\text { 7. Chestnut } \\
\text { honey (n=3) }\end{array}$ & $<0.5$ & $74 \pm 2$ & $1.0 \pm 0.5$ & $4.2 \pm 1.2$ & $15.9 \pm 1.7$ & $0.82 \pm 0.09$ & $2.0 \pm 1.0$ \\
\hline $\begin{array}{l}\text { Variation } \\
\text { interval }\end{array}$ & $<\mathbf{0 . 5}$ & $\mathbf{3 2 - 7 4}<\mathbf{1 - 2 . 0}$ & $\mathbf{1 . 9 - 1 1 . 1}<\mathbf{1 0 - 2 1 . 5}<\mathbf{1 - 0 . 8 2}$ & $<\mathbf{1 - 2 . 2}$ \\
\hline
\end{tabular}

When it comes to artificial (anthropogenic) radionuclides, the activity of cesium-137 was recorded, but only in the honey samples originating from the area of Kosovo and Metohija (Table 2). A total of 15 samples from different 
localities were tested, and the presence of biologically significant ${ }^{137} \mathrm{Cs}$ radionuclide was determined at eight localities (which represents more than $50 \%$ of the total tested samples). It is important to note that all the measured activities of the isotope cesium-137 in the analysed honey samples are below the maximum allowable values (Official Gazette of RS, No. 36/2018).

Table 2. The results of measurements of radionuclides in honey from the area of Kosovo and Metohija

\begin{tabular}{cccccccc}
\hline $\begin{array}{c}\text { Radio- } \\
\text { nuclides }\end{array}$ & Cs-137 & K-40 & Th-232 & Ra-226 & U-238 & U-235 & Na-22 \\
\hline Locality & \multicolumn{7}{c}{ Activity concentration $[\mathrm{Bq} / \mathrm{kg}]$} \\
\hline $\mathbf{1 .}$ & $1.62 \pm 0.19$ & $88 \pm 3$ & $0.82 \pm 0.10$ & $6.14 \pm 0.38$ & $<1$ & $<0.2$ & $<0.5$ \\
\hline $\mathbf{2 .}$ & $0.41 \pm 0.12$ & $77 \pm 3$ & $1.04 \pm 0.10$ & $6.53 \pm 0.35$ & $<1$ & $<0.2$ & $1.37 \pm 0.09$ \\
\hline $\mathbf{3 .}$ & $<0.7$ & $123 \pm 5$ & $1.64 \pm 0.20$ & $10.4 \pm 1.0$ & $<1$ & $<0.2$ & $<0.5$ \\
\hline $\mathbf{4 .}$ & $<0.6$ & $100 \pm 6$ & $1.15 \pm 0.21$ & $4.67 \pm 0.53$ & $<1$ & $<0.2$ & $1.59 \pm 0.17$ \\
\hline $\mathbf{5 .}$ & $1.43 \pm 0.25$ & $68 \pm 4$ & $0.99 \pm 0.20$ & $2.44 \pm 0.48$ & $<1$ & $<0.2$ & $1.44 \pm 0.16$ \\
\hline $\mathbf{6 .}$ & $0.42 \pm 0.11$ & $70 \pm 4$ & $0.83 \pm 0.11$ & $6.80 \pm 0.33$ & $13.8 \pm 3.7$ & $0.71 \pm 0.19$ & $1.43 \pm 0.08$ \\
\hline $\mathbf{7 .}$ & $0.52 \pm 0.06$ & $106 \pm 2$ & $0.84 \pm 0.06$ & $11.1 \pm 0.3$ & $12.5 \pm 2.1$ & $0.64 \pm 0.11$ & $1.46 \pm 0.06$ \\
\hline $\mathbf{8 .}$ & $1.85 \pm 0.18$ & $103 \pm 3$ & $0.99 \pm 0.13$ & $4.35 \pm 0.33$ & $13.6 \pm 3.5$ & $0.70 \pm 0.18$ & $1.59 \pm 0.09$ \\
\hline $\mathbf{9 .}$ & $<0.6$ & $96 \pm 4$ & $1.67 \pm 0.19$ & $24.8 \pm 0.9$ & $<1$ & $<0.2$ & $2.94 \pm 0.16$ \\
\hline $\mathbf{1 0 .}$ & $<0.4$ & $43 \pm 2$ & $1.11 \pm 0.10$ & $7.52 \pm 0.33$ & $<1$ & $<0.2$ & $<0.5$ \\
\hline $\mathbf{1 1 .}$ & $<0.3$ & $34 \pm 2$ & $0.90 \pm 0.08$ & $9.20 \pm 0.31$ & $25.8 \pm 5.4$ & $1.32 \pm 0.28$ & $1.53 \pm 0.07$ \\
\hline $\mathbf{1 2 .}$ & $<0.2$ & $35 \pm 2$ & $0.88 \pm 0.10$ & $4.52 \pm 0.32$ & $31.4 \pm 7.6$ & $1.61 \pm 0.39$ & $1.42 \pm 0.09$ \\
\hline $\mathbf{1 3 .}$ & $<0.3$ & $112 \pm 4$ & $1.09 \pm 0.11$ & $15.6 \pm 0.42$ & $<1$ & $<0.2$ & $1.64 \pm 0.10$ \\
\hline $\mathbf{1 4 .}$ & $3.63 \pm 0.31$ & $107 \pm 5$ & $1.01 \pm 0.20$ & $4.06 \pm 0.48$ & $<1$ & $<0.2$ & $1.72 \pm 0.14$ \\
\hline $\mathbf{1 5 .}$ & $1.61 \pm 0.29$ & $94 \pm 6$ & $1.96 \pm 0.38$ & $7.34 \pm 0.67$ & $<1$ & $<0.2$ & $2.40 \pm 0.29$ \\
\hline $\begin{array}{c}\text { Vari- } \\
\text { ation }\end{array}$ & $<0.2-3.63$ & $34-123$ & $0.82-1.67$ & $2.44-15.6$ & $<1-31.4$ & $<0.2-1.61$ & $<0.2-2.40$ \\
interval & & & & & & & \\
\hline & & & & & & & \\
\hline
\end{tabular}




\section{DISCUSSION}

As can be seen form the tables, the highest activity was determined for radioactive potassium-40. In the tested samples, its activity ranged from $32 \mathrm{~Bq} /$ $\mathrm{kg}$ (Table 1) to $123 \mathrm{~Bq} / \mathrm{kg}$ (Table 2). The values obtained for the concentration of ${ }^{40} \mathrm{~K}$ activity are in agreement with the results reported by other authors (Borawska et al., 2013; Pöschl et al., 2011). The ${ }^{40} \mathrm{~K}$ activity increased according to the type of honey in the following order: sunflower, flower (polyfloral), linden, meadow, acacia, rapeseed and chestnut. From a biological and ecological point of view, ${ }^{40} \mathrm{~K}$ is one of the most important natural radioactive elements. This radionuclide easily moves from the soil to plants and animals, and through foods of plant and animal origin, like honey it can also reach the human body. Since it is in the soil and in the human body, potassium-40 causes external and internal irradiation of all tissues, and especially radiation of soft tissues in the human body. Potassium is under homeostatic control in the body and it is estimated that the annual effective dose received by the human body as the result of the presence of ${ }^{40} \mathrm{~K}$ is $165 \mu \mathrm{Sv}$ (Pavlović and Nikezić, 1995). From the obtained results, it can also be concluded that radioactive potassium-40 mostly contributes to the natural radioactivity of honey.

The measured activity of the natural radioisotope in the tested honey samples ranged between $<0.2$ and $2.40 \mathrm{~Bq} / \mathrm{kg}$. These ${ }^{22} \mathrm{Na}$ activities are common for most of the samples from the nature. It is estimated that the annual level of ${ }^{22} \mathrm{Na}$ intake by ingestion is about $50 \mathrm{~Bq}$ which contributes to the annual effective doze of $0.15 \mu \mathrm{Sv}$ (Pavlović and Nikezić, 1995). As a cosmogenic radionuclide that is formed in the constant interaction of cosmic radiation with various atoms and molecules in the atmosphere, earth and water, from the radioecological point of view it is not of great importance for the radiation safety of the biosphere.

The measured activity of the natural radionuclide in honey ranged from 0.82 to $2.0 \mathrm{~Bq} / \mathrm{kg}$. The measured values of ${ }^{232} \mathrm{Th}$ activity were in agreement with the values reported by other authors (Dizman et al., 2020). Various accidents at nuclear power plants can lead to a significant increase in the concentration of this radionuclide in food. If ${ }^{232} \mathrm{Th}$ released in this way reaches the food chain, it can be deposited in bone tissue, lungs and liver, and thus increase its radioecological significance in the overall radiation of the population. The average daily intake of ${ }^{232} \mathrm{Th}$ through food in the Republic of Serbia is $1.76 \mathrm{mBq}$ (Đujić, 1995).

When it comes to natural radionuclides in uranium samples, the presence of uranium-238 and radium-226 was registered. The activity of ${ }^{238} \mathrm{U}$ was in the range between $<1$ and $31.4 \mathrm{~Bq} / \mathrm{kg}$, which is significantly higher than the values 
reported by other authors (Đurić and Popović, 2000) while the activity of ${ }^{226} \mathrm{Ra}$ ranged between 1.9 and $15.6 \mathrm{~Bq} / \mathrm{kg}$. The presence of these isotopes in honey is of great concern because U-238 and its derivatives Ra-226 and radon-222 pose the greatest risk for human health (Dangić, 1995). The total daily intake of ${ }^{238} \mathrm{U}$ through food is $12.48 \mathrm{mBq}$ and the average daily intake of ${ }^{226} \mathrm{Ra}$ in Serbia is $52.3 \mathrm{mBq}$ which corresponds to the average intake of ${ }^{226} \mathrm{Ra}$ in other countries, and its estimated annual dose is between 20 and $30 \mu \mathrm{Sv}$ (Đujić, 1995). Due to the very long physical and biological half-life, its amount in the body increases over time. The measured U-235 activity was in the range of $<0.2$ and $1.61 \mathrm{~Bq} /$ $\mathrm{kg}$. In the body, uranium acts as a toxicant because it is a source of ionizing radiation, and also a chemically toxic element. The kidneys are critical organs for natural uranium and its isotopes because if they reach the lungs, they quickly pass into the blood and are eliminated from the body through the kidneys (Mitrović, 2001).

The results of honey contamination measurements, which are shown in Table 1 and Table 2, indicate that the most intense contamination comes from the artificial radionuclide cesium-137. It ranged from $<0.2$ to $3.63 \mathrm{~Bq} / \mathrm{kg}$. Similar results for ${ }^{137} \mathrm{Cs}$ activity in honey and detection limit for most of the examined samples are reported by Beňová et al. (2019). This activity is particularly important because ${ }^{137} \mathrm{Cs}$ is a biologically important radionuclide which, if it reaches the human body through the food chain, is distributed to all organs almost evenly. The analysis of the ${ }^{137} \mathrm{Cs}$ content in the soil shows that there is a stronger binding of this radionuclide to the surface layers of the soil ( 0 - 40 $\mathrm{cm}$ ), while its migration to deeper layers $(40-80 \mathrm{~cm})$ is significantly slowed down. These results are in full agreement with previous research on the deep penetration of ${ }^{137} \mathrm{Cs}$, which showed that about $80 \%$ of its activity is retained in the surface layer of the soil.

It is interesting to point out the fact related to the radio contamination of bees. Given that honey is a bee product, it would make sense to assume that the bee organism itself will be significantly contaminated. However, since bees have a short lifespan, this contamination cannot in any way affect the bee as a living organism, especially because insects as a species are known to be very resistant to ionizing radiation even at doses of a few tens of Gy, which are otherwise supraleathal for humans (Hadžimuratović et al., 1987). Also, when exposed to microwave radiation, bees did not show any abnormalities related to the ability to fly, orientation, memory and efficiency in performing work (Terzin, 2010).

Many studies of the radiochemical composition of honey (Mihaljev et al., 2001) found multiple links between the mineral composition of honey (con- 
tent of natural radionuclides and other micro and macro elements) and its geographical and botanical origin. This means that by applying appropriate statistical methods, certain types of honey can be very successfully identified as well as classified according to their geographical origin. The results indicate that the activity of natural radionuclides in honey varies depending on the geochemical characteristics of the soil, the proximity of industrial plants and that the content of radionuclides depends on the type of vegetation - honey flora (Đurić et al., 1996).

\section{CONCLUSION}

The presence of biologically significant radionuclides, both natural ${ }^{238} \mathrm{U}$, ${ }^{235} \mathrm{U}$ ) and artificial $\left({ }^{137} \mathrm{Cs}\right)$, was determined in some analyzed honey samples. Therefore, it is necessary to systematically study radioactive substances in bee pastures - their identification, distribution and quantity in the system of soilhoney plant species-honey. Numerous radionuclides found in the nature with the potential to concentrate locally in honey in the levels that are dangerous for the health of the population, call for the need to carry out appropriate systematic research in order to prevent harmful effects of ionizing radiation.

Increasing intake of radionuclides from anthropogenic sources like accidents at nuclear power plants, application of phosphate fertilizers, pollution from thermal power plants and the use of ammunition with "depleted uranium" pose significant risks to public health and environmental protection. Honey bee and its products and specific properties can serve as some kind of "environmental guard" because many changes and pollutants in the nature are quickly repercussed on bees that are very sensitive to any changes in the environment and react immediately to pollution (pesticides, toxic elements, radionuclides) that we normally do not notice. Therefore, honey, as the final product of bees and pollen deserves special attention when considering radioactive contamination.

The obtained results are of great importance for the protection of the environment of the examined areas because these data can be a reference since they represent a "zero state" in the case of future anthropogenic activities that may cause additional contamination. Regarding the determined concentrations of the activity of the tested radionuclides, it can be concluded that honey produced in the Republic of Serbia is a healthy and environmentally safe food and does not pose a radiation risk to human health. 


\section{ACKNOWLEDGEMENT}

This research was funded by the Ministry of Education, Science and Technological development of Republic of Serbia by the Contract of implementation and financing of scientific research work of NIV-NS in 2021, Contract No: 451-03-9/2021-14/200031 and was also supported by Provincial Secretariat for Agriculture, Water Management and Forestry of Vojvodina, Contract No: 104401-4672/2021/01.

\section{Author's Contribution:}

$\check{Z} M$ and MŽB made contributions to the idea of the publication, organisation of work and writing the manuscript; $\check{Z} \mathrm{M}$ and NP did the laboratory analysis; and SJ, MŽB and NP reviewed the manuscript and participated in the final draft of the manuscript.

\section{Competing interest}

The authors declare that they have no competing interests.

\section{REFERENCES}

1. Beňová K., Dvořák P., Špalková M. 2019. Radiocaesium in Honey from Košice and Prešov Regions in Eastern Slovakia. Folia Veterinaria, 63, 4, 27-32. doi: 10.2478/fv-2019-0034.

2. Bikit I., Slivka J., Čonkić Lj., Krmar M. 1995. Specifični problemi merenja prirodnih radionuklida. In Monografija-Jonizujuća zračenja iz prirode. Ed. M. Kovačević, Jugoslovensko društvo za zaštitu od zračenja, Beograd, 263-289.

3. Blagojević M., Simić B. 2012. Oblici i izvori ugrožavanja ekološke bezbednosti, Ecologica, 19, 66, 185-188.

4. Borawska H. M., Kapała J., Puścion-Jakubik A., Horembała J., MarkiewiczŽukowska R. 2013. Radioactivity of Honeys from Poland after Fukushima Accident. Bulletin of Environmental Contamination and Toxicology, 91, 489-492. doi:10.1007/s.00128-013-1089-1.

5. Dangić A. 1995. Geohemijski procesi u prirodi i radionuklidi. In Monografija-Jonizujuća zračenja iz prirode. Ed. M. Kovačević, Jugoslovensko društvo za zaštitu od zračenja, Beograd, 41-56.

6. Dizman S., Hodolli G., Kadiri S., Aliu H., Makolli S. 2020. Radioactivity in Kosovo Honey Samples. Polish Journal of Environmental Studies, 29, 2, 1119-1127. doi: 10.15244/pjoes/105968. 
7. Đujić I.S. 1995. Prirodni radionuklidi u hrani. In Monografija-Jonizujuća zračenja iz prirode. Ed. M. Kovačević, Jugoslovensko društvo za zaštitu od zračenja, Beograd, 373-385.

8. Đurić G. and Popović D. 2000. Uranijum u životnoj sredini, Hemijska Industrija, 54 (2), 50-52.

9. Đurić G., Popović D., Todorović D., Slivka J., Mihaljev Ž. 1996. Natural and fallout radionuclides in different types of honey. Journal of environmental biology, 17(4), 339-343.

10. Hadžimuratović M., Horšić E., Milošević Z., Sabirović M., Nevjestić A. 1987. Radioaktivna kontaminacija meda, peluda i saća u cenztralnoj i sjeveroistočnoj Bosni. In Zbornik radova, 10. Kongres Pčelara - Savez pčelarskih organizacija Jugoslavije, Kragujevac, 169-172.

11. IAEA (International Atomic Energy Agency) 1989. Measurement of Radionuclides in Food and the Environment, Vienna.

12. Mihaljev Ž., Popović D., Đurić G., Slivka J. 1992. Natural radionuclides in honey. Acta Veterinaria, 42, 5-6, 343-346.

13. Mihaljev Ž., Živkov-Baloš M., Đilas S. 2001. Results of measuring heavy metals and other micro- and macro elements in honey. Veterinarski glasnik, 55, 3/4, 167-172.

14. Mitrović R. 2001. Radioaktivnost u životnoj sredini, Vrelo, Beograd, 39-41.

15. Ortec. 2015. Gamma Vision ${ }^{\circledR}$ Gamma-Ray Spectrum Analysis and MCA Emulator for Microsoft ${ }^{\circledR}$ Windows ${ }^{\circledR}$ 7, 8.1, and 10 Professional A66-BW.

16. Pavlović S., Nikezić D. 1995. Nivoi izloženosti jonizujućem zračenju iz prirode i metode za proračun doza. In Monografija-Jonizujuća zračenja iz prirode. Ed. M. Kovačević, Jugoslovensko društvo za zaštitu od zračenja, Beograd, 335-360.

17. Pöschl M., Pridal A., Duchova I. 2011. Radioactivity of Honeybee Honey in the Czech Republic. Analele Universităţii din Craiova, seria Agricultură-Montalonologie-Cadastru Vol. XLI, 225-230.

18. Sl. Glasnik br. 36/2018: Pravilnik o granicama sadržaja radionuklida u vodi za piće, životnim namirnicama, stočnoj hrani, lekovima, predmetima opšte upotrebe, građevinskom materijalu i drugoj robi koja se stavlja u promet.

19. Stanimirović Z., Soldatović B., Vučinić M. 2000. Medonosna pčela, Univerzitet u Beogradu, Fakultet veterinarske medicine, Medicinska knjiga, Medicinske komunikacije, 299-304.

20. Terzin T. 2010. Medonosna pčela-Jevanđelje prirode, Preporod, Beograd, 313-316. 
21. Vorgić M. 2004. Uloga pčele u ekosistemu. In Zbornik radova, Pčelarstvo i životna sredina, Društvo pčelara «Jovan Živanović», Novi Sad, 7-8.

Received: 08.12.2021.

Accepted: 29.12.2021. 